\title{
Dignity: An Essential Foundation for Promoting Health and Well-Being
}

\author{
Berit Sæteren and Dagfinn Nåden
}

\section{Abstract}

The purpose of this chapter is to illuminate different understandings of the concept of dignity and to discuss how we can make use of this knowledge to enhance human health. Dignity is viewed as a universal concept in health sciences and a feature necessary to promote health and alleviate suffering related to sickness and impending death. The ideas presented in this chapter are founded in a caring science paradigm where the human being is considered as a unique entity consisting of body, soul, and spirit. Caring science as referred to in this chapter has its scientific foundation in Gadamer's ontological hermeneutics.

Dignity is described in a historical perspective, and different meanings of dignity are clarified. Since health and dignity relate to one other, we have clarified the concept of health employing the texts of the Finnish theoretician Katie Eriksson. In order to illuminate the perspective of health promotion, we have also briefly described health in a salutogenic perspective according to the medical sociologist Aron Antonovsky. In clarifying dignity, the

B. Sæteren $(\bowtie) \cdot$ D. Nåden

Faculty of Health Sciences, Department of Nursing and Health Promotion, Oslo Metropolitan University, Oslo, Norway

e-mail: beritsa@oslomet.no; dagfinn@oslomet.no texts of well-known researchers from the Nordic countries and UK were employed. In reflecting on how we can make use of the knowledge of dignity and indignity to promote health, we have considered this matter in light of results of a major Scandinavian study. The main purpose of this study was to explore dignity and indignity of patients in nursing homes from the perspective of patients, family caregivers, and health personnel. The testimonies presented in this section are further interpreted employing mainly caring science and philosophical literature. Lastly, a short summary of some public policy efforts with the aim to preserve human dignity is offered.

\section{Keywords}

Dignity $\cdot$ Indignity $\cdot$ Health $\cdot$ Health promotion $\cdot$ Well-being

\subsection{Introduction}

The purpose of this chapter is to illuminate different understandings of the concept of dignity and to discuss how we can make use of this knowledge to enhance human health.

Dignity is a core concept in nursing science and care, as well as in other health professions that take responsibility for the health and wellbeing of others [1-5]. In nursing, the preservation of human dignity is often emphasized as nursing 
is related to persons in vulnerable situations and in need of health care. The value of protecting human dignity is often emphasized colloquially and in professional and political settings without necessarily explaining what it really means. Consequently, no common understanding of dignity exist; thus, the health professionals are left with their individual interpretation of the meaning of dignity. Furthermore, a concept, which is used in several different context and with different meanings, is at risk of becoming meaningless. Theoretical end empirical research is therefore valuable to broaden our understanding of dignity in the health care context.

A common understanding is that human beings are unique creations with an inherent dignity and are given a specific place in the world [2-4, 6-10]. Likewise, the experience of dignity is significantly meaningful in people's lives and may be a resource for personal health and wellbeing. Vulnerability and dependency are basic features of human existence. As other creatures manage their own life when born, human beings have a special existential vulnerability and dependency on being seen and taken care of by others. Vulnerability is always a part of human life, actualized in situations where humans need help from their closest family members or from health care professionals [11, 12]. Vulnerability is however also a positive trait by being human, a health resource, helping persons to transform demanding experiences from life and sickness into strength and personal growth [13].

Dignity is often characterized as a complex and vague concept. Although a large amount of research related to dignity has been done in recent years, the meaning of the concept is still ambiguous. This may not be considered a problem but instead a strength, as it points to the complexity in conceptualizing a human phenomenon as complicated as dignity $[14,15]$.

In this chapter, the aim is to broaden the significance and meaning of the concept in a historical and professional setting based on theory and research. We do not offer a particular definition of dignity. Moreover, we emphasize the meaning and importance of dignity as a health resource in people's lives and how promoting dignity can help persons to experience well-being and be restored to health. Tranvåg and McSherry [16] claim that nurses as well as allied health care professionals may have an intuitive understanding of dignity in their practice, but they often lack the in-depth understanding required to manifest dignity in practical situations. Indignity/violation of dignity in health care is well known and documented [5, 17]. It is therefore important that health personnel working with people in vulnerable situations seek to obtain a deeper understanding of the underlying components of dignity in order to promote health, foster humane health care, and prevent dehumanization. Buchanan [18] even emphasizes promoting dignity as the ethical dimension of health.

Dignity is viewed as a universal concept in health sciences and a feature necessary to promote health and alleviate suffering related to sickness and impending death. In this chapter, we want to call attention to the value of the concept related to experiences of health and health promotion. We understand health promotion in line with the Ottawa Charter from 1986 as "the process of enabling individuals and communities to increase control over the determinant of health and thereby improve their health." ([19], p. 15). The ideas presented in this chapter are founded in a caring science paradigm where the human being is considered as a unique entity consisting of body, soul, and spirit [2, 7, 20]. Caring science as referred to in this chapter has its scientific foundation in Hans-Georg Gadamer's [21] ontological hermeneutics. The idea of hermeneutics is to clarify terms for understanding of the human being.

\subsection{Dignity in a Historical Perspective}

Human dignity has held a prominent place in political discussions of human rights since the Second World War [22]. Dignity emerges as a right and a duty based on a notion of human rights that relates to inner value and objective beauty in the human being entailing strong moral implications for fellow human beings. Each person deserves respect, and because of the human 
being's dignity and inner value, the person holds a certain right that the world community must protect. The United Nations [23] emphasizes that all human beings have inherent dignity. Article 1 of the Universal Declaration of Human Rights [23] states:

All human beings are born free and equal in dignity and rights. They are endowed with reason and conscience and should act towards one another in a spirit of brotherhood.

Professional codes such as the ICN Code of Ethics for Nurses [24] emphasize that the preservation of dignity is an important part of caring. "Inherent in nursing is a respect for human rights, including cultural rights, the right to life and choice, to dignity, and to be treated with respect."

The idea of dignity has a long history. In ancient Rome, the Latin dignitas meant "worthiness," and in a political context, "reputation" or "standing." Sensen [22] distinguishes between what he calls a contemporary and a traditional paradigm related to human dignity. The contemporary paradigm relates to human rights, and the traditional paradigm goes back to older thinkers such as Pico della Mirandola and Immanuel Kant [22]. In contrast to the contemporary paradigm related to human rights, the traditional understanding is primarily a theoretical question about the human being's place in the universe because of its rationality and freedom. Dignity is used in the traditional sense to describe the special position that human beings hold. Because of this special position, the human being has an initial dignity as well as a duty to realize it. Sensen [22] describes these two notions of dignity as "initial dignity" and "realized dignity."

In 1988 Katie Eriksson [1] (p. 22) expressed that Human dignity is the human being's ability to constitute her life and being. She based her thesis on the work Praise of man's dignity (published in 1486) by the Renaissance philosopher Giovanni Pico della Mirandola (1463-1494). According to Pico, human beings were exceptional in the Creation. He viewed the dignity of human beings as founded in their freedom, in their capacity to choose their own place in the chain of beings stretching from God to the lowest animals [22, 25, 26].
Later, the German philosopher Immanuel Kant (1724-1804) described dignity as an absolute inner value that all human beings possess. $\mathrm{He}$ refers to dignity as an elevated position, above the rest of the nature, by virtue of a certain capacity, namely freedom and reason. Kant talks about dignity mainly in relation to the duty toward oneself not to violate the prerogative one has over other creatures [22]. The historical perspectives of the meaning of dignity are still visible in the contemporary view of the concept.

\subsection{Dignity and Health}

Health and dignity relate to each other [4]. In traditional health and medical care the focus has been related more to illness than to health. In a health-promoting perspective, the focus is moving toward person's health resources. This perspective is clarified both in Eriksson's caring science theory [2, 7] and in Aron Antonovsky's $[27,28]$ salutogenic model of health. They both acknowledge suffering and disease as part of human life but find it more valuable to focus on the strength and resources, which are imparted in each human being in order to handle challenges related to illness and life. Conceptually and historically, health means wholeness and holiness [7]. Wholeness relates to a person's unseparated being as body, soul, and spirit. Holiness refers to a person's deep awareness of her uniqueness and responsibility as a fellow human being. Both health and suffering are parts of human life, and according to Eriksson $[7,8]$, there is an inherent dialectic between them. As human beings, we live in this dialectical movement between health as wholeness and integration and suffering as divineness and disintegration. Antonovsky [27] also described health as movement on a continuum of ease and dis-ease. According to Antonovsky [27], we are always exposed to events in life that may be considered as stressors. This can reduce health temporarily but can also make a person stronger [28]. Sense of coherence is a key concept in Antonovsky's salutogenic model. The sense of coherence points to a person's view of life and 
capacity to handle stressful situations. As human beings, we have the capacity to comprehend the situation we are in as comprehensive, meaningful, and manageable, thereby strengthening our sense of coherence in life [27, 28].

Eriksson [29] defines health in her earlier writings based on an analysis of the concept: health as soundness, freshness, and well-being. She strongly emphasizes the subjective dimension of health and health as more than the absence of illness. This is in line with Antonovsky' model. In many situations, we are not able to promote health in the sense of soundness and freshness, but in most cases, we are able to promote well-being. This will be exemplified later in this chapter.

Eriksson [7] views health in its deepest sense as an ontological concept relating to the individual's becoming and reality. She presents an ontological health model where health is a movement between three separate levels: health as doing, being, and becoming. This movement is expressed in the person's experiences of various problems, needs, or desires. At the doing level, health is related to objective external criteria; at the being level, people strive to experience a form of harmony and balance; and at the becoming level, a person is not a stranger to suffering and strives to be whole and to reconcile herself with the given circumstances. Life is movement. Human beings live in a dialectical movement between different binary opposites such as life and death, health and suffering, and dignity and indignity. To balance these opposites is the human being's responsibility and represents his personal life struggle. The direction the movement takes depends on various circumstances. These may be related to the person himself, his relationship to others, to God, or an external power, nature, or the surrounding environment [30, 31]. Among the human being's noble traits are the ability and freedom to choose the direction for this inner movement. This inner movement is not unaffected by a person's relations and circumstances, "No man is an island." This is especially true when the person's vulnerability is acute and dignity is threatened. This may happen for humans considering themselves as healthy as well as for people in obvious need of health care. The respect and confirmation of a person's strength and health resources given by health personnel are of great importance in promoting or restoring dignity when it is threatened [32, 33].

\subsection{The Meaning of Dignity from Theoretical and Empirical Research}

Researchers have tried to clarify dignity through theoretical and empirical studies. Investigations of the concept of dignity and its field of meanings have represented an important step in understanding the essence of dignity.

Despite ontological and empirical differences, one shared feature is the understanding of dignity as a dualistic concept [16]. This has been described in various terms. Eriksson [6], Edlund [8], and Edlund et al. [9] refer to absolute and relative dignity. Absolute dignity is recognized as an inherent, inviolable, and unchangeable dimension rooted in human holiness. Absolute dignity consists of values such as responsibility, freedom, duty, and service. Relative dignity comprises a bodily, external, esthetic dimension and a physical inner ethical dimension. Relative dignity is changeable and is influenced by internal and external factors.

Other theorists use the term objective dignity [3], Menneschewürde [10], and human dignity [4] to denote absolute dignity. These different terms for this dimension of dignity are rooted in human worth and human equality [23]; common features in their descriptions of dignity are dignity as inherent, universal, unchangeable, and inviolable.

Jacobson [4] describes relative dignity as social dignity and mentions two intertwined aspects of social dignity: dignity-of-self and dignity in-relation. Dignity-of-self relates to selfrespect, self-confidence, autonomy, and various forms of integrity. Dignity in-relation refers to the way in which respect and worth are conveyed back to the individual through expression and recognition. Relative dignity and social dignity may be lost, or gained, threatened, violated, or promoted. Jacobson [5] claims that any human 
interaction may be an encounter with dignity [5] in which dignity is either promoted or violated. Also Nordenfelt [10] and Nordenfelt and Edgar [34] address the dimensions of dignity similarly, pointing to relative and social dignity through notions such as (1) dignity as merit based on formal position and rank, (2) dignity as moral stature based on personal moral values, and (3) dignity as identity based upon personal autonomy, integrity and self-respect, and also influenced by relationships and interaction with others. Relative and/or social dignity can be violated as well as supported and promoted. Relative dignity is the subjective part of dignity, and knowledge of what values are important for the individual person will always be the basis for dignity-preserving care.

As bodily changes frequently are a threat to persons in need of health care, research underscores the connection between bodily changes and dignity. Edlund [8] and Edlund et al. [9] describe the body as the bearer of relative dignity. The body often serves as a symbol for dignity when it performs actions in accordance with the culture's rules and norms for dignity. The body may also be a potential source of violation when bodily changes make it impossible to perform what both the human being and the culture of fellow humans expect. The body enables independence and freedom, but also limitations and dependency. The body generates both pride and shame and opens for vulnerability, violation, power, and powerlessness. The body is an important part of the holistic human being, a unity that must be whole to experience dignity. Bodily changes may lead to suffering and be a violation of the person's dignity [8].

It is a question as to whether it is fruitful to maintain the division between absolute and relative dignity. Research related to dignity and bodily changes in a palliative care setting questions this division. Lorentsen et al. [14, 15] emphasize patients' and relatives' need to strive for dignity in situations where patients' bodies are falling apart because of advanced cancer disease. Through the ambiguity and paradox of the body, dignity was revealed as a life-affirming will and love as healing power [15]. The relatives' confirmation of the ambivalent or rather paradoxical body was grounded in the fundamental love for the family member and an act of responsibility, both bricks in the concept of dignity. The complexity of the body lead to the question of whether the division between absolute and relative dignity was inapplicable when understanding dignity in a bodily perspective [14]. This question needs more theoretical and empirical research.

Finally, we want to shed light on an aspect of dignity related to health personnel. Gallagher [3] explored dignity as both an "another-regarding" and a "self-regarding" value: respect for the dignity of others and respect for one's own personal and professional dignity. Respect for the dignity of others is well known and the object of much attention within health professions, while respect for one's own dignity is given less attention. Other-regarding and self-regarding values appear to be inextricably linked, and Gallagher refers to Aristotle's doctrine of the mean, which enables health personnel to reflect on the appropriate degree of respect for the dignity of others and proper respect for themselves. In encounters between patients and health care personnel in our multicultural world, there may be situations of personal and cultural nature that may be challenging, and the self-respect and self-worth of the professional may be threatened.

The meaning of dignity may be summarized theoretically, as it has been a commonly shared notion among researchers that dignity has an unchangeable dimension related to just being born. The grounds of the human inherent value may differ, from a religious version, which is grounded in a belief that human beings hold an exalted place in God's creation, where life is created and given. A secular version associated with Kant is grounded in the rationality of human beings and their ability to act as moral agents as enshrined in The Universal Declaration of Human Rights (1948) [4]. Relative dignity is harder to grasp, as the subjective part of dignity will be different according to a person's own personal values, context and culture. To give an exact definition of dignity is therefore difficult because it describes the fundamental meaning of being human [4]. 


\subsection{Making Use of the Knowledge of Dignity and Indignity to Promote Health}

In the following section, we will describe and discuss from different perspectives how we can understand and make use of the knowledge of dignity and indignity to promote health, having in mind the importance of nurturing the inner strength in old people living in nursing homes [35-37]. We will consider this matter in light of the results of a major Scandinavian study called A life in dignity, the main purpose of which was to explore the dignity and indignity of patients in nursing homes from the perspective of patients, family caregivers, and health personnel $[31,38$, 39]. The overall study had a hermeneutical design inspired by Gadamer's philosophy [21]. Individual interviews were performed with 28 residents (17 women and 11 men between 62 and 103 years), 28 family caregivers (children and spouses) and qualitative focus group interviews with health care personnel, a total of 40 staff members with five to eight participants in every interview session. The number of group sessions varied between three and four sessions, totally 20 meetings. Twelve researchers were involved, and the study was carried out in nursing homes in Norway, Sweden, and Denmark. The data material was read and interpreted by the entire research group until consensus about the results was reached. The study followed the guidelines for good scientific practice, set by the ethics committees in the Scandinavian countries [17]. Our intention in including the following presentation is not to present the study itself, but to make use of parts of the results to illustrate both dignified and undignified care in clinical practice.

\subsection{Learning from the Perspective of Health Care Personnel}

In the following, we present two different pictures in which dignity is preserved.

A helper's testimonies:
Some years ago, a woman with dementia was admitted to this nursing home, and she was awfully shy and scared, sitting with her purse and looking down at the floor ... her hair covered her eyes. We had no contact with her; it was quite impossible. I think we tried for two hours ... and then I thought ... we must try something else. So, I did something no one else had done before, I think, I lay down on the floor and crawled under the table. Then I looked up at her face and smiled at her and said, "Hey there!" And then I got this beautiful smile back! And every time after that incident, she recognized me and gave me this beautiful smile, and said to me, 'Hey there!' [40]

One of our residents has serious dementia and has no family caregivers, and he loves to watch soccer; he likes Vålerenga (a well-known soccer club in Norway). Then I thought to myself, I love soccer, but I hate Vålerenga. However, I can still watch one Vålerenga match (I thought). So, I sent an e-mail to the club and told about our resident with dementia, 82 years old... And there we went. He was dressed in a dark suit and we were seated in the VIP tribune and we were treated with this and that ... but what joy we shared! This was my day off duty, but we were together, both enthusiastic, and all the glances, and all the pleasant things we shared. This is what I hope my mother and father will experience in a nursing home, things they like ... This is my passion! [40]

These two narratives deal with fostering dignity and promoting health, in this case in individuals who suffer from dementia living in a nursing home. The caregivers, visualized in the stories, show a deep dedication in helping human beings who suffer. We have labeled these two narratives dignity as distinction, meaning individuality implying respect, listening, eye contact, vocal pitch, body posture, calmness, and friendliness. Dignity is also feeling accepted as unique and complete persons [40]. Even while attending a soccer match, we experience a deep communion between the resident and the caregiver, along with togetherness, enthusiasm, and joy. The motivation for displaying this kind of attitude is aptly stated by the caregiver: Human beings grow when they are met with dignity [40].

Dignity is also seen as influence and participation through the opportunity to participate and being able to co-determine their daily activities. Through creativity, awareness and sensitivity, the health personnel had the opportunity to enhance 
the residents' ability to influence their own lives [40]. Nygren et al. [35] underline the importance of inner strength in being an oldest old person. The caregivers in this present study 'lived' the inner strength for those people not having the capacity possessing this quality, that nevertheless created strength and empowered the residents [40].

Both accounts relate encounters which are dimensions of caring as an art. In an investigation Nåden and Eriksson [41] concluded that the encounter is characterized by being on the same wavelength, giving oneself over, "nakedness," and of deep solidarity and closeness. One of the most human qualities is manifested in the encounter, when the person is in contact with him or herself. The encounter can be healing, life-giving, and alleviating, and the participants are first and foremost human beings. We can read these dimensions in the narratives above; the patients' wishes and needs. As one caregiver states: One ought to be sensitive and look at facial expressions ... If one does not see the other human being, then dignity is at risk [40]. A character in a novel by Erik F. Hansen, a well-known Norwegian author, says the following about art: I'm over sixty and I have never found out what it [art] depends on. What is it that separates the genuine from the false, the genuine from the superficial, and what is it that makes one person an artist and another a craftsman ([42], p. 229).

For something to be called an art and not just a craft, it must be linked and connected to a foundational idea. In music it is called cantus firmus, the fundamental melody, which has its origin in Renaissance polyphony. In the same manner, caring and nursing become an art performance that will preserve the individual's dignity in both patients and health personnel [41]. There is an inherent obviousness in the turn to the other, where a deep ethical attitude is evident in the caregiver. It is an example of what Eriksson [2, 43] terms the mantra of caring ethics: I was there, I saw, I witnessed, and I became responsible. It is also in line with Levinas' thoughts [44-46] when he writes about the ethics of the face, becoming responsible for the other.

Levinas writes about human responsibility and freedom in context, claiming that "I am called to a responsibility that was never contracted, inscribed on the other's face. Nothing is more passive than this accusation that precedes any freedom." ([45], p. 100). According to Levinas [45] the ability to be affected by the vulnerability and suffering of others is a prerequisite for man to assume the responsibility that is given to us and already is there. The caregivers in the stories above possess this ability to be touched, which is why we can speak of a natural inherent obviousness in the turn to the other. Likewise, this demonstrates the very importance of Levinas thinking in understanding the given responsibility for the other, in our case, the patients, where the caregivers lift the other so that the other can preserve his or her dignity, and experience health as becoming [2]. This is in line with the patients' wishes in Bylund-Grenklo [47] research in a palliative care context where a dignified life was about having their human value maintained by others through "coherence." Levinas emphasizes the perfection of artistic creation, the ultimate moment when the last brushstroke is made, when not a single word can be added to or subtracted from the text [45]. In light of these words, we can see the perfection of the art performance in our context, when the face and the beautiful smile were perceived by the old lady with dementia. Everything that could and should be done was done; nothing less and nothing more was needed. The last brushstroke was done with the two words: hey there! Levinas [45] claims that the artist stops because the work refuses to receive more. The artist in this narrative from clinical practice knew that at this moment, the work that these two people created together was complete. From the stories and our interpretations, we can understand, more deeply and more thoroughly, what dignity is about.

\subsection{Learning from the Perspective of Family Caregivers}

Brief stories from family caregivers show what dignity is for their loved one and for themselves: Just after a short while, my mother went to 
concerts, bingo, church ceremonies, hobby days, digital book days and reading-aloud days. She participated in everything that was going on. She became a new human being, became healthier. Now she appreciates life ([48], p. 513). This is consistent with Nygren et al.'s [35] research stating that inner strength opens up the possibility of acceptance of new realities. Feeling that one is the same person even though circumstances have changed gives a feeling of stability.

The spirit in which care is given influences the way patients and their relatives see the little extra and helps to promote the dignity of patients and thus their health: There are some of them who do the little extra-making an omelet or doing some decoration, food and drinks, something a little extra ([48], p. 513).

An expression of the staff's attitude from the perspective of the family caregivers reveals what it means when the patient is really seen as an individual with dignity. A commitment from the caregiver to look for common interests with the resident can be interpreted as creating a communion or a caring relationship [48].

Dignity as "at-home-ness" is also important for the family caregivers: I felt warm right away, as soon as she came here, she had a value. Another statement: In my experience of older persons, it is more important that they feel safe than to be in a fancy surrounding, that they are cared for! When they get to a stage in life when they no longer can take care of themselves, they really have enough just trying to care for themselves ([48], p. 512).

Family caregivers also experience situations that are the opposite of at-home-ness. They experienced situations where their dear ones became abandoned. Being deprived of dignity through physical humiliation is one kind of abandonment. One family caregiver describes feeding situations that verge on violations of law and the use of physical force [17]. In addition to hurting the residents, the caring situations were non-esthetic:

I have seen such terrible feeding situations. Totally insensitive and soulless feedings where one sits and continuously spoons food into the residents' mouths. And I, who am sitting alongside, notice that the poor human being has not swallowed any of what they just popped in his mouth. After the last ten spoonfuls, the food comes out again. The health personnel can sit and shovel food into someone at the same time as they are talking to other persons in the room or are talking on their cell phone. It makes me feel terribly sorry for the patient. This behavior is not dignified care. As a matter of fact, it has upset me very often ([17], p. 756).

From the perspective of the caregivers, one can understand the abandonment in both concrete and existential ways. In the concrete way, the residents are left alone. In the existential way, they are not met and seen when they most need it, as presented in this feeding situation [17].

To be abandoned touches deeply human sensitivities since human beings are dependent on each other. To be deprived of togetherness with other human beings or with an abstract other can abandon the individual to loneliness and despair. This experience may be perceived even worse when the individual is old, has a physical or psychological disability, or has dementia. As Nåden et al. [17] (p. 757) express: It is especially depressing when violation occurs in a professional context where personnel are meant to care for the individual in an appropriate manner. Nursing home residences are built for individuals to let them live the last years of their lives in safe surroundings and get health care from personnel with high caring ideals as their compasses.

The relatives also stressed the importance of the specific caregiver. Some staff members are just there for the job and are perhaps not interested in providing the little extra. If the "wrong" person gives care, the resident can be ignored. As one of the relatives noted, doing the little extra is when the residents are really seen by caregivers who are suited for their jobs and can see the beauty in the faces of the older persons ([48], p. 513). Levinas argues that the other's face does not expose the arbitrariness of the will, but its injustice. Nor does the evidence of my injustice appear when I bow to facts, but when I bow to the Other ([45], p. 53) he points out.

In this light, we can clearly see the degrading feeding situation in the above narrative. The helpers who are meant to bow to the other-in this case, those who are supposed to provide care for the persons in need, supporting them in building 
up their inner strength-instead turn away from them. They are prevented from seeing the other because they do not approach them. It is when approaching the other that the other's face appears to me, according to Levinas ([45], p. 53) not as a threat or an obstacle, but as something that is of importance to me.

The helpers refuse to be "the chosen ones," as Levinas [45] (p. 158), talks about. In this case this means that it is the other, the patient, that chooses me, not the opposite. To be struck by the other's face does not mean that I am set free for selfexpression. On the contrary, it means that I am linked to the responsibility. The family caregivers highly value this form for responsibility from the helpers taking care of their dear ones [48].

\subsection{Learning from the Perspective of Patients}

What seemed to be common to almost all the residents at the nursing homes was the fact that moving into the nursing home was experienced as a threat to their dignity. The threat was related to the perception that they were becoming dependent on others, that there was a lack of time and resources on the unit, and that they were being deprived of freedom, but it was also related to the attitudes of health care personnel [49]. We present narratives of both indignity and preserved dignity.

The residents related humiliating situations in which the health care personnel were rude, impolite, and paternalistic: Three times they have told me that they are not my slaves when I asked for help - two times when I asked for help with my ostomy, and once when I asked them if they could help me fold up my quilt. And they asked, 'Do you think this is a hotel?' ([49], p. 44).

I think to myself that I should be a free man, but I'm not free. If I get dressed and want to go out, I'm not allowed to go out. "You have to stay inside", they say. They say that if I want to go out, I need to have someone with me, or I can't go. That's how it is. They think I'm too weak. And I can agree that I was weak when I moved into that other place. But there is never a damned soul to take me out. Never! ([49], p. 44).
Freedom is closely linked with dignity. Freedom means that a person is free to do and use the inner strength to act or to decide for himself or herself, as well as freedom from something, such as force or paternalism. To possess autonomy implies that you construct for yourself the laws you are to follow [50]. The resident above states that he has no freedom, which is the opposite of what he had imagined. The loss of freedom can feel like a double loss for this man in that no helpers can follow him out. In this sense, the loss of physical freedom will also have consequences for the person's inner freedom. Heggestad et al. [51] found that several patients in the nursing home felt they were in captivity, like a prison without bars. In the stories above, we also experience inappropriate language from the caregivers. Rudeness, impoliteness, and paternalistic attitudes described by the residents demonstrate the asymmetric relationship between the residents and the caregivers [49]. This might be construed as abuse of power. Rundquist [52] states that power belongs to all human beings and is thus ontological-a matter of human nature. The author further states that power is given to human beings only as authority. The authoritative human being takes responsibility for his/her human office, but abandoning it means abandoning oneself and one's dignity.

The humiliating situations above are examples of misuse of power by the caregivers, a power that is not given to them by the patients in need of help. It is the opposite of ontological power that is rooted in intuitive and esthetic knowledge [53] and which does not turn the patient into a victim. Knowledge of ontological power can be linked to and is consistent with Watson's [54] statement that care necessitates a moral obligation to protect human dignity.

In line with Watson [54], Pieranunzi [53], and Rundqvist [52], Foss et al. [55] elaborate on responsibility and leadership, positing the other as the real leader. When transferred to a clinical context, the patient becomes the real leader and guiding star. This is in sharp contrast to the story told by the patient above who was deprived of his freedom, and it contrasts with the humiliation related by the family caregiver earlier in this chapter. 
On the positive side, one resident explains the meaning of still being able to participate in an activity she had been part of earlier in her life: $I$ like to dance. I have danced for 20 years. I dance once a week, and the bus comes and picks me up. I am the only one from the nursing home. However, the nursing home organizes dancing in the afternoon for everyone. I think it's great that they arrange that, because I like it so much ([56], p. 95). The resident feels respected and valued, when the nursing home recognized her resources and inner strength and made it possible to participate in an activity that had been a part of her previous social life and which attracted attention from others in her current life.

Two other residents are positive about their situations:

I'll need help to take a shower. But it is ok to be helped by others. Once a young man had to assist me. I was a little concerned about that, but when he helped me, I thought it was fine and the other ladies also liked to be assisted by him ([56], p. 95).

Another lady tells I love being helped. It is not degrading. No, I am not ashamed of it. It's okay. So, I feel mostly like a baby (laughs) ([56], p. 95).

Most residents regarded asking for help as a potential threat, and growing dependency was one of the harder adjustments they faced. Residents described these experiences in different ways. Some felt that they had been robbed of their freedom, whereas others felt valued as persons and found that the help they received improved their quality of life. In order to retain their dignity, it seemed significant to be able to make sense of the unavoidable circumstances in their lives and remain positive [56].

The quality of these meetings is of the utmost importance for those who need help to maintain their dignity. In some ways, an encounter entails going into deep water. The apprehension associated with an encounter can be altered and transformed into something greater: honesty and authenticity. On the wavelength that the encounter occurs, the person is in contact with both the self and the other. This is the profoundest level of health, where the germ and opportunity for growth are found [41]. In such a description of the encounter, the caregiver has found his place, where the potential for growth is present for both parties. In situations like this, a great responsibility is shown toward the patients. Eriksson [43] refers to Hellqvist who claims that responsibility also means a "solemn declaration." It is through a solemn declaration that we can convey the message of love that we truly desire the well-being of others. It is an assurance of the other's dignity.

\subsection{Public Policy Efforts to Preserve Human Dignity}

Preserving patients' dignity is not only a responsibility of the health care professional, the family, and the patient himself. It is a political responsibility. In this short section, we briefly summarize laws and regulations in the Scandinavian countries and the UK for which the aim is to preserve human dignity.

In 2011 a new national value system was implemented in the Social Services Act (2001) in Sweden [57], stipulating that elderly care shall promote a dignified life and the feeling of wellbeing. Local dignity guarantees are based on the national set of values for older people stipulated in the Social Services Act, which means that care of elderly people provided by social services has to focus on older people being able to live their lives in dignity and feel a sense of well-being. Similarly, The Patients' Right Act in Norway from 1999 [58] states that the provisions of the act shall help to promote a relationship of trust between the patient and the health service and safeguard respect for the life, integrity, and human dignity of each patient. In 2011, the regulation relating to "Dignity Guarantee" in elderly care entered into force in Norway [59]. The regulation aims to ensure that the care of older people is carried out in such a way that it contributes to a dignified, safe, and meaningful retirement. In 2019 Health Care Denmark presented a new white paper called "A dignified elderly care in Denmark." [60] It is stated in the foreword of this white paper that Denmark is to have a dignified elderly care system with focus on involving and empowering every citizen and an emphasis on their individual needs and preferences. 
In the Health and Social Care Act (2008), United Kingdom, Regulation 2014 [61] states that service users must be treated with dignity and respect. It includes ensuring the privacy of the service user, supporting the autonomy, independence, and involvement in the community of the service user, and has any relevant protected characteristics of the Equality Act of the service user. Staff must always treat service users with dignity and respect, which means treating them in caring and compassionate ways. They must be respectful when communicating with service users, using the most suitable means of communication and respecting a person's right to engage or not to engage in their communication.

Documents like those mentioned above may contribute to a change in health care services culture in general and in nursing homes in particular, where the focus of care is on the person, not the task, as Robinson and Gallagher [62] underline, and likewise protect patients exposed to unethical acts, so that they can regain a kind of pride and dignity $[63,64]$. To make a change, leaders have a crucial role to play in the promotion of dignity in care.

It is interesting to note that there is a need to enact laws and regulations on something as basic as respect for human dignity. The legislation in the examples above show the importance of supporting dignity in care, but in some of the texts of these regulations, there seems to be a lack of clarity about the meaning of the concept of dignity. A consequence of this might be that it is up to the individual reader of the text and the health personnel to understand the concept of dignity.

\subsection{Conclusion}

Even though there is a shared feature that dignity is important in people's life and being, and because the fact that dignity is used in political and professional settings, the meanings of dignity are seldom described. Therefore, the purpose of this chapter was to illuminate different understandings of the concept of dignity and to discuss how we can make use of this knowledge to promote and enhance human health and well-being.
Researchers have tried to clarify the concept through theoretical and empirical work. Some of these theories are presented. The theories show that there is a shared feature that dignity is a dualistic concept. One dimension is recognized as inherent dignity, which is unchangeable and rooted in human worth and equality. The other dimension is related to the subjective part of being human and dependent of a person's value system, context, and culture. This dimension can be violated as well as promoted. Hence, any human interaction may be an encounter with dignity and thereby a health promoting interaction.

Dignity is a core concept in caring, and health personnel need knowledge of the meaning of dignity in health care. There is a need of both theoretical knowledge and empirical knowledge visualized through narratives about the art of caring. In the second part of this chapter, we present testimonies from health care personnel, family caregivers, and patients. Reflections about the encounters between patients and caregivers together with knowledge about dignity may be one way to make use of the developed knowledge and the possibilities imparted in the concept of dignity in order to promote health. Both political leaders and leaders within health care have a crucial role in facilitating health care that preserves person's dignity.

\section{Take Home Messages}

- Dignity is a person's ability to constitute life and being.

- Dignity is a dualistic concept. Dignity consists of an inherent and absolute dignity which is universal, unchangeable, and inviolable and a relative dignity which is changeable and influenced by internal and external factors.

- Each human interaction may be an encounter where dignity is either promoted or violated.

- It is important to promote the inner strength of the other person to support her or him to live a life in dignity.

- Acknowledgment of and responsibility for the other person is part of performing the art of nursing care.

- Dignity is an essential foundation for promoting health and well-being. 


\section{References}

1. Eriksson K. Vårdvetenskap som disciplin, forskningsområde och tillämpningsområde (Caring Science as discipline, research area and practice). Vasa: Åbo Akademi University; 1988.

2. Eriksson K. Vårdvetenskap. Vetenskap om vårdandet. Om det tidlösa i tiden. (Caring science. The science of caring. About the timeless time). Stockholm: Liber; 2018.

3. Gallagher A. Dignity and respect for dignity-two key health professional values: implications for nursing practice. Nurs Ethics. 2004;11(6):587-99.

4. Jacobson. N. Dignity and health: a review. Soc Sci Med. 2007;64:292-302.

5. Jacobson N. Dignity violation in health care. Qual Health Res. 2009;19(11):1536-47.

6. Eriksson K. Om människans värdighet (On human dignity). In: Bjerkreim T, Mathisen J, Nord R, editors. Visjon, viten og virke (Vision, knowledge and profession). Oslo: Universitetsforlaget; 1996.

7. Eriksson K. The suffering human being. Chicago: Nordic Studies Press; 2006.

8. Edlund M. Människans värdighet - ett grundbegrepp innom vårdvetenskap (Human dignity—a basic caring science concept). (Dissertation). Åbo: Åbo Akademi University Press; 2002.

9. Edlund M, Lindwall L, Von Post I, Eriksson K. Concept determination of human dignity. Nurs Ethics. 2013;20(8):851-60.

10. Nordenfelt L. The varieties of dignity. Health Care Anal. 2004;12(2):69-81.

11. Martinsen K. Care and vulnerability. Oslo: Akribe AS; 2006.

12. Martinsen K. Løgstrup og sykepleien (Løgstrup and nursing). Oslo: Akribe AS; 2012.

13. Malterud K, Solvang P. Vulnerability as a strenght: why, when, and how? Scand J Public Health. 2005;33(Suppl 66):3-6.

14. Lorentsen VB, Nåden D, Sæteren B. The paradoxical body: a glimpse of a deeper truth through relatives' stories. Nurs Ethics. 2018;26(6):1611-22. https://doi. org/10.1177/09697330118768660.

15. Lorentsen VB, Nåden D, Sæteren B. The meaning of dignity when the patients' bodies are falling apart. Nurs Open. 2019;2019.6(1):1163-70.

16. Tranvåg $\mathrm{O}$, McSherry $\mathrm{W}$. Understanding dignity: a complex concept of the heart of healthcare. In: Tranvåg O, Synnes O, McSherry W, editors. Stories of dignity within healthcare. Research, narratives and theories. Stuart, FL: GB, M\&K Publishing; 2016.

17. Nåden $\mathrm{D}$, Rehnsfeldt $\mathrm{A}$, Råholm $\mathrm{MB}$, Lindwall L, Caspari S, Aasgaard T, Sletteb Å, Sæteren B, Høy B, Lillest $\varnothing$ B, Heggestad AK, Lohne V. Aspects of indignity in nursing home residences as experienced by family caregivers. Nurs Ethics. 2013;20(7):748-61. https://doi.org/10.1177/0969733012475253.

18. Buchanan DR. Promoting dignity: the ethical dimension of health. Policy Theor Soc Iss. 2016;36(2):99104. https://doi.org/10.1177/0272684X16630885.
19. Rannestad T, Haugan G. Helsefremming i kommunehelsetjenesten (Health promotion in municipal health). In: Haugan G, Rannestad T, editors. Health promotion in municipal health. Oslo: Cappelen Damm Akademisk AS; 2014.

20. Eriksson K. Vårdandes idè (The idea of caring). Stockholm: Almqvist \& Wiksell; 1987.

21. Gadamer HG. Truth and method. London: Sheed \& Ward Ltd and the Continuum Publishing Group; 1989.

22. Sensen O. Human dignity in historical perspective: the contemporary and traditional paradigms. Eur J Polit Theor. 2011;10(1):71-91. https://doi. org/10.1177/1474885110386006.

23. United Nations. Universal declaration of human rights. Now York: UN; 2015. p. 1948.

24. ICN. The ICN code of ethics for nurses; 2012.

25. Pico GM. Oratio. In: Frost T, editor. Giovanni Pico della Mirandola. Lovprisning av menneskets verdighet. Om det værende og det ene (Praise og man's dignity). Latvia: Vidarforlaget; 2013.

26. Kaldestad K. Menneskets verdighet i kraft av det hellige rommet (Human dignity in virtue of the sacred space). (Dissertation). Finland: Åbo Akademi University Press; 2018.

27. Antonovsky A. Hälsans mysterium (Unraveling the mystery of health). Stockholm: Bokförlaget Natur och Kultur; 2009.

28. Eriksson M. The sense of coherence in the salutogenic model of health. In: Mittelmart MB, et al., editors. The handbook of Salutogenesis; 2017. https://doi. org/10.1007/978.3-319-04600-6_11.

29. Eriksson K. Hälsans idè (The idea of health). Stockholm: Almqvist \& Wiksell; 1984.

30. Sæteren B, Lindström UÅ, Nåden D. Latching onto life: living in the area of tension between the possibility of life and the necessity of death. J Clin Nurs. 2010;20:811-8. https://doi. org/10.1111/j.1365-2702.2010.03212.x.

31. Sæteren B, Heggestad AK, Høy B, Lillestø B, Sletteb A, Lohne V, Råholm MB, Caspari S, Rehnsfeldt A, Lindwall L, Aasgaard T, Nåden D. The dialectical movement between deprivation and preservation of a person's life space. A question of nursing home residents' dignity. Holist Nurs Pract. 2016;6(30):139-47.

32. Sæteren B. Kampen for livet I vemodets slør (Struggling for life in the veil of pensiveness). (Dissertation). Finland: Åbo Akademi University Press; 2006.

33. Sæteren B, Lindström UÅ, Nåden D. I still have so much to do - struggling for life when time is limited. Int J Hum Caring. 2015;19(1):57-62.

34. Nordenfelt L, Edgar A. The four notions of dignity. Qual Ageing. 2005;6(1):17-21.

35. Nygren B, Norberg A, Lundman B. Inner strength as disclosed in narratives of the oldest old. Qual Health Res. 2017;17(8):1060-73.

36. Lundman B, Alex L, Jonsen E, Løvheim H, Nygren B, Fischer RS, Strandberg G, Norberg A. Inner strength in relation to functional status, disease, living arrangements, and social relationships among people aged 85 years and older. Geriatr Nurs. 2012;33(3):167-76. 
37. Franklin L-L, Ternestedt B-M, Nordenfelt L. Views on dignity of elderly nursing home residents. Nurs Ethics. 2006;13(8):130-46. https://doi.org/10.1191/0 969733006ne851oa.

38. Nåden D. A life in dignity. International innovation. Disseminating science, research and technology. EuroFocus: Health. 2013;2013:32-4.

39. Lindwall L, Råholm MB, Lohne V, Caspari S, Heggestad AK, Sæteren B, Sletteb $\varnothing$ Å, Høy B, Nåden D. Clinical application research through reflection, interpretation and new understanding - a hermeneutic design. Scand J Caring Sci. 2018;32:1152-67.

40. Lohne V, Høy B, Lillestø B, Sæteren B, Heggestad AKT, Aasgaard T, Caspari S, Rehnsfeldt A, Råholm MB, Sletteb $\varnothing$ Å, Lindwall L, Nåden D. Fostering dignity in the care of nursing home residents through slow caring. Nurs Ethics. 2016;24(7):778-88. Accessed 10 Feb 2020. https:// doi.org/10.1177/0969733015627297.

41. Nåden D, Eriksson K. Encounter: a fundamental category of nursing as an art. Int J Hum Caring. 2002;6(1):34-9.

42. Hansen EF. Psalm at journey's end (J. Tate, Trans.). London: Secher \& Warburg; 1997. Original work published 1990.

43. Eriksson K. Jag var där, jag såg, jag vittnade och jag blev ansvarig - den vårdande etikens mantra (I was there, I saw, I witnessed, and I became responsible - the mantra of caring ethics). In: Alvsvåg H, Bergland Å, Førland O, editors. Nødvendige omveier. En vitenskapelig antologi til Kari Martinsens 70-års dag. (Necessary detours. A scientific anthology to Kari Martinsen's 70 years anniversary). Oslo: Cappelen Damm Akademisk; 2013.

44. Kemp P. Emmanuel Lévinas. En introduktion (Emmauel Levinas. An introduction). Gothenburg: Daidalos; 1992.

45. Aarnes A. Emmanuel Levinas. Underveis mot den annen (Along the way towards the other). Essays av og om Levinas ved Asbjørn Aarnes. Oslo: Vidarforlaget A/S; 1998.

46. Levinas E. Den Annens Humanisme (The Humanism of the Other). Original title: Humanisme de l'autre homme (1972). Trondheim: Det Norske Akademi for Sprog og Litteratur; 2004.

47. Bylund-Grenklo T, Werkander-Harstäde V, Sandgren A, Benzein E, Östlund U. Int J Palliat Nurs. 2019;25(4):193-201.

48. Rehnsfeldt A, Lindwall L, Lohne V, Lillestø B, Slettebø Å, Heggestad AKT, Aasgaard T, Råholm MB, Caspari S, Høy B, Sæteren B, Nåden D. The meaning of dignity in nursing home care as seen by relatives. Nurs Ethics. 21(5):507-17.

49. Heggestad AKT, Høy B, Sæteren B, Slettebø $\AA$, Lillest $\varnothing$ B, Rehnsfeldt A, Lindwall L, Lohne V, Råholm M-B, Aasgaard T, Caspari S, Nåden D. Dignity, dependence, and relational autonomy for older people living in nursing homes. Int J Hum Caring. 2015;19(3):42-6.
50. Caspari S, Råholm M-B, Sæteren B, Rehnsfeldt A, Lillest $\varnothing$ B, Lohne V, Sletteb $\AA$, Heggestad AKT, Høy B, Lindwall L, Nåden D. Tension between freedom and dependence- a challenge for residents who live in nursing homes. J Clin Nurs. 2018;27:4119-27.

51. Heggestad AKT, Nortvedt P, Sletteb $\varnothing$ A. 'Like a prison without bars': dementia and experiences of dignity. Nurs Ethics. 2013;20(8):881-92.

52. Rundqvist E. Makt som fullmakt. Et vårdvetenskapligt perspektiv (Power as authority. A caring science perspective). (Dissertation). Åbo, Finland: Åbo Akademi University Press; 2004.

53. Pieranunzi VR. The lived experience of power and powerlessness in psychiatric nursing: a Heideggerian hermeneutical analysis. Arch Psychiatr Nurs. 1997;XI(3):155-62.

54. Watson J. Nursing: human science and human care. A theory of nursing. New York: National League for Nursing Press; 1988.

55. Foss B, Nåden D, Eriksson K. Experience of events of truth in hermeneutic conversation with text: ethics and ontology. Nurs Sci Q. 2016;29(4):299-307.

56. Høy B, Lillest $\varnothing$ B, Sletteb $\varnothing$ Å, Sæteren B, Heggestad AKT, Caspari S, Aasgaard T, Lohne V, Rehnsfeldt A, Råholm M-B, Lindwall L, Nåden D. Maintaining dignity in vulnerability: a qualitative study of the residents' perspective in nursing homes. Int J Nurs Stud. 2016;60:91-8.

57. Ministry of Health and Social Affairs, Sweden. The Social Services Act. 2001. https://ec.europa.eu/antitrafficking/sites/antitrafficking/files/social_services_ act_sweden_en_1.pdf. Accessed 1 Feb 2020.

58. The Norwegian Government. The Patients' Rights Act. 1999. https://app.uio.no/ub/ujur/oversatte-lover/data/ lov-19990702-063-eng.pdf. Accessed 1 Feb 2020.

59. Ministry of Health and Care Services. Forskrift om en verdig eldreomsorg (The dignity guarantee regulation). 2011. https://lovdata.no/dokument/SF/ forskrift/2010-11-12-1426?q=Verdighetsgarantien. Accessed 1 Feb 2020.

60. A dignified elderly care in Denmark. White Paper. Health Care Denmark. https://www.healthcaredenmark.dk/news/new-white-paper-a-dignified-elderlycare-in-denmark/. Accessed 2 Feb, 2019. 2020.

61. Regulation 10 of the Health and Social Care Act 2008, United Kingdom, Regulation 2014. https:// app.croneri.co.uk/care-standards/cqc-fundamentalstandards-england/regulation-10-dignity-and-respect. Accessed 17 Feb 2020.

62. Robinson GE, Gallagher A. Culture change impacts quality of life for nursing home residents. Top Clin Nutr. 2008;23(2):264-72.

63. Heijkenskjöld KB, Ekstedt M, Lindwall L. The patients' dignity from the nurses' perspective. Nurs Ethics. 2010;17(3):301-11.

64. Hall EOC, Нøy B. Re-establishing dignity: nurses' experiences of caring for older hospital patients. Scand J Caring Sci. 2012;26:287-94. 
Open Access This chapter is licensed under the terms of the Creative Commons Attribution 4.0 International License (http://creativecommons.org/licenses/by/4.0/), which permits use, sharing, adaptation, distribution and reproduction in any medium or format, as long as you give appropriate credit to the original author(s) and the source, provide a link to the Creative Commons license and indicate if changes were made.

The images or other third party material in this chapter are included in the chapter's Creative Commons license, unless indicated otherwise in a credit line to the material. If material is not included in the chapter's Creative Commons license and your intended use is not permitted by statutory regulation or exceeds the permitted use, you will need to obtain permission directly from the copyright holder.

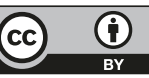

